Asian J. Med. Biol. Res. 2016, 2 (3), 402-408; doi: 10.3329/ajmbr.v2i3.30110

\author{
Asian Journal of \\ Medical and Biological Research \\ ISSN 2411-4472 (Print) 2412-5571 (Online) \\ www.ebupress.com/journal/ajmbr
}

\title{
Article \\ Antidiabetogenic impact of bitter melon (Momordica charantia) and garlic (Allium sativum) on alloxan induced diabetic rabbit model
}

Ambiara $^{1}$, Fahima Binthe Aziz ${ }^{2}$, Md. Mahmudul Hasan ${ }^{3 *}$, Md. Shajedur Rahman ${ }^{4}$ Misrat Masuma Parvez ${ }^{6}$, Kishor Kumar Roy ${ }^{6}$ and Md. Anowarul Haque ${ }^{7}$

${ }^{1}$ Department of Physiology \& Pharmacology, Hajee Mohammad Danesh Science and Technology University, Dinajpur, Bangladesh

${ }^{2}$ Department of Physiology \& Pharmacology, Hajee Mohammad Danesh Science and Technology University, Dinajpur, Bangladesh

${ }^{3 *}$ Department of Physiology \& Pharmacology, Hajee Mohammad Danesh Science and Technology University, Dinajpur, Bangladesh

${ }^{4}$ Department of Medicine, Surgery \& Obstetrics, Hajee Mohammad Danesh Science and Technology University, Dinajpur, Bangladesh

${ }^{5}$ Department of Physiology \& Pharmacology, Hajee Mohammad Danesh Science and Technology University, Dinajpur, Bangladesh

${ }^{6}$ Department of Physiology \& Pharmacology, Hajee Mohammad Danesh Science and Technology University, Dinajpur, Bangladesh

${ }^{7}$ Department of Surgery \& Obstetrics, Bangladesh Agricultural University, Mymensingh, Bangladesh

*Corresponding author: Md. Mahmudul Hasan, Assistant Professor, Department of Physiology \& Pharmacology, Hajee Mohammad Danesh Science \& Technology University, Dinajpur, Bangladesh. Phone: +8801721785830; E-mail: m.hasanvet@gmail.com

Received: 24 August 2016/Accepted: 05 September 2016/ Published: 29 September 2016

\begin{abstract}
The present study was undertaken to investigate the antidiabetic effect of the Bitter melon and Garlic on Alloxan induced diabetes in experimental rabbits. At 2 to 3 months of age, rabbits were assigned into five groups (A, B, C, D and E) and each group was remained 4 rabbits. Group A was kept for control, Group B was treated with Alloxanintramuscullarly at a dose of $75 \mathrm{mg} / \mathrm{kg}$ body weight, Group C was treated with bitter melon $250 \mathrm{gm} / \mathrm{kg}$ body weight orally, Group D was treated with garlic $750 \mathrm{mg} / \mathrm{kg}$ body weight orally, Group E treated with combined at previous dose. After acclimatization, diabetes was induced in four groups of rabbits (B, C, D and E) by administering Alloxan injection in a dose of $75 \mathrm{mg} / \mathrm{kg}$ body weight (b.wt.) intramuscularlly. There was significant decreased in blood glucose level in all treated group C, D, E compared to the B group and lowest glucose was recorded in E group when treated with combined medicinal herbs and body weight was increased in all treated group C, D, E compared to the B group and highest was recorded in Dgroup while treated with those.\% of PCV level and $\mathrm{Hb}$ gm/dl concentration was the highest in group $\mathrm{E}$ which was treated with both garlic and bitter melon compare to the A group. ESR was highest in group B treated with Alloxan and lowest in group E. The present study reveals that combined treatment increases body weight and decreases glucose level without affecting health of rabbits.
\end{abstract}

Keywords: alloxan; garlic; bitter melon; dibetes

\section{Introduction}

Medicinal plants continue to be an important therapeutic aid for alleviating ailments of humankind. A lot of research work has been carried out on some medicinal herbs and they have been found to have definite action on the nervous, circulatory, respiratory, digestive and urinary systems; as well as the sexual organs, the skin, vision, 
hearing and taste (Bailey et al., 1989). Diabetes mellitus is a wide spread disorder which has long been in the history of medicine. World Health Organization (WHO) estimates that 346 million people suffer from diabetes worldwide. Despite continuous introduction of the modern drugs, diabetes and its related complication is still a global medical issue. Before the advent of synthetic insulin and oral hypoglycemic drugs, the major form of treatment involved the use of plants (Wadkar et al. 2008). Diabetes mellitus can be chemically or surgically induced in different animal species. Chemical induction of diabetes can be achieved by injecting uric acid, dial uric acid, dehydro ascorbic acid, quinoline and magnesium. However, the most commonly used means of chemical induction of diabetes has been either alloxan or streptozotocin, as their diabetogenic dose is usually 4 to 5 times less than their lethal dose. However Guinea pigs are totally insensitive to alloxan (Gordsky et al., 1982). Alloxan (mesoxal urea) was the first chemical used to induce experimental diabetes. It was found by Leibig in mucus excreted during dysentery (Merck Index, 1976). The diabetogenicdose of alloxan vary considerably amongst species, age and metabolic state of the animal. Nephrotoxicity is also a side effect (Bonar, 1980). Momordicacharantia (M. charantia), is a popular plant used for treating of diabetes related conditions. Fruits and leaves of most wild Momordica species are consumed as vegetables and have a similar bitter taste and almost identical medical uses. It has been used as a traditional antidiabetic remedy in eastern countries for many years. Bitter melon suppresses weight gain and has the potential to reduce adiposity (Chen et al., 2003). Bitter melon may possess insulin-like properties, preserved pancreatic islet beta cells (Ahmed et al., 1998). A recent study proved that bitter melon could upregulate the significance of glucose transporter 4 (GLUT-4), peroxisome proliferator-activated receptor $\gamma(\operatorname{PPAR} \gamma)$ and phosphatidylinositol 3 kinase (PI3K) by augmenting the glucose uptake and homeostasis (Kumar et al., 2009). It can also improve insulin sensitivity by increasing insulin-stimulated insulin receptor substrate-1 (IRS1) tyrosine phosphorylation in high-fat diet-fed mice/rats (Nerurkar et al., 2008 and Sridhar et al., 2008). Allium sativum (Garlic) contains chemically active substances such as enzymes, amino acids, minerals and sulphur containing compounds such as alliin (S-allyl cysteine sulphoxide (SACS) and allicin (diallyldisulphide) which are responsible for garlic's pungent odour and many of its medicinal effects (Murray and Pizzorno, 1999). Garlic has been found to have antibacterial and antifungal activity, reduce aortic plaque deposits (Durak et al., 2002) inhibits vascular calcification in human patients with high blood cholesterol (Durak et al., 2004) reduce hyperlipidemia (Kojuri et al., 2007; Mader, 1990) and hyperglycaemia (Ojo, 2012). The objective of this study is to evaluate the Alloxan induced diabetes occurred in experimental rabbits and investigate the combined effect of Momordicacharantia (Bitter melon) and Allium sativum (Garlic) in Alloxan induced diabetic rabbit and to study the effects of plants suspension on body weight, blood sugar, in experimental rabbits.

\section{Materials and Methods}

Twenty healthy white rabbit aged between 2 to 3 months and weighting between 1000 to1200g were collected from rabbit farm under the department of Animla Genetics and Breeding, Hajee Mohammad Danesh Science and Technology University, Dinajpur and grouped into A, B, C, D \& E and each group contain 4 rabbits. Group A was kept as normal control, group B was kept as positive control (Alloxan administered). Group C was kept as treatment 1(Alloxan+bitter melon), Group D treatment 2 (Alloxan+garlic) and Group E treatment 3(Alloxan+bittermelon+garlic).The rabbits were maintained for a period of two weeks to acclimatize them prior to experimental uses. Twenty rabbits were used to carry out this investigation. These rabbits were divided into five groups containing 4 rabbits in each group. The groups were designated and maintained as follows:

Group A: This group of rabbits served as normal rabbits. Body weights and blood glucose level were measured at the time when that of other groups was measured. This group was served as normal control group.

Group B: Alloxan hydrochloride injection was given at a dose rabbits of $75 \mathrm{mg} / 1000$ to1200gm (Puri and Prabhu, 2002) in intramuscular route to each rabbits to induce diabetes. The rabbit were fed normal diet and given water adlibitum from Day 1-15 on 15th day blood glucose level and the body weight were again measured to ensure diabetic condition. Then all the rabbit of this group were kept for 14 days without any treatment. During that period on Day $0,7 \& 14$ the body weight and blood glucose level were measured. This group served as diabetic (positive) control group.

Group C: Alloxan hydrochloride was injected in all rabbits of this group at a dose rabbits of $75 \mathrm{mg} / \mathrm{kg}$ in intramuscular route. The rabbits were fed normal diet and given water adlibitum for 15 days. Then blood glucose level and body weight were measured on 15th day of Alloxan hydrochloride injection for confirming diabetic condition. After that suspension of bitter melon fed at a dose of $250 \mathrm{gm}, 3 \mathrm{~mL}$ water/1000 to $1200 \mathrm{gmb}$.w./day for 21 days. During treatment of bitter melon suspension body weight and blood glucose level were recorded on Day 0 (Pre-treatment) and Day 7, $14 \& 21$ (during treatment). This group served as treatment group 1to find the effect of suspension of bitter melon as antidiabetic drug. 
Group D: Alloxan hydrochloride was injected in all rabbit of this group at a dose rabbits of $75 \mathrm{mg} / \mathrm{kg}$ in intramuscular route. The rabbits were fed normal diet and given water ad libitum for I5days. Then blood glucose level and body weight were measured on 15th day of Alloxan hydrochloride injection for confirming diabetic condition. After that suspension of garlic were fed at a dose of $750 \mathrm{mg} / \mathrm{kg}$ body weight/day for 14 days. During treatment of suspension of black cumin seed body weight and blood glucose were recorded on Day 0 (Pretreatment) and Day 7, $14 \& 21$ (during treatment). This group served as treatment group 2to find the effect of suspension of black cumin seed as antidiabetic drug.

Group E: Alloxan hydrochloride injection was given at a dose rabbits of $75 \mathrm{mg} / 1000$ to1200 gmin intramuscular route to each rabbits to induce diabetes. The rabbit were fed normal diet and given water ad libitum from Day 115 on 15th day blood glucose level and the body weight were again measured to ensure diabetic condition. After that suspension of bitter melon and garlic were fed at a previous dose for 14 days. During combined treatment of suspension of bitter melon and black cumin seed body weight and blood glucose were recorded on Day 0 (Pre-treatment) and Day 7, 14 \& 21 (during treatment). This group served as treatment group 3 to find the combined effect of suspension of bitter melon and black cumin seed as antidiabetic drug.

Fresh bitter melon and garlic are purchased from the local market at a reasonable price then these are measured separately by electronic balance and grinded with mortar and pestle than blended with blender machine. Finally, the extracts are mixed with $100 \mathrm{ml}$ distilled water separately and stirred to make homogenous mixture and then filtered through silk cloth.

Body weight and fasting blood glucose level of each rabbits were measured after 18 hours of fasting before Alloxan injection, 72 hours of after Alloxan injection and Day 0 (Pre-treatment) and Day 7, 14 \& 21 (during treatment) of different treatment.

Body weight was taken on day 0 (pretreatment), 7, 14 and 21(during treatment). The data were analyzed with SPSS statistics 20.0 software. Probability $\mathrm{P}<0.05$ was considered statistically significant.

\section{Results and Discussion}

To perform the experiment, twenty rabbits were randomly divided into five equal groups. Alloxan was injected (I/M) at the dose rate of $75 \mathrm{mg} / \mathrm{kg}$ body weight to the groups of rabbits $(\mathrm{B}, \mathrm{C}, \mathrm{Dand} \mathrm{E})$ for induction of diabetic syndrome. Group A rabbits were kept as non-diabetic (Normal) control without giving Alloxan and any other treatment. Group B rabbits were kept as diabetic control without (giving any other treatment except Alloxan). Next two groups of rabbits (C and D) were treated with suspension of bitter melon fruit at dose of $250 \mathrm{gm} / \mathrm{kg}$ and garlic at a dose of $750 \mathrm{mg} / \mathrm{kg}$ for consecutive 21 days respectively after 21 days of Alloxan administration. All the control and treated rabbits were closely observed 21 days of treatment period.

\subsection{Blood Glucose Level $(\mathrm{mmol} / \mathrm{L})$}

\subsubsection{Alloxan induced diabetics and comparison with control}

Blood glucose level of different groups of rabbits are presented in Table-1.The study was revealed that glucose level was the highest in group B, which was treated with Alloxan compare to the A group. This treatment significantly $(\mathrm{p} \leq .0 .05)$ increase the blood glucose level in treated rabbits. The present results are agreed with other results of Lenzen,2008; Tasaka et al., 1988; West et al., 1996 suggested that Alloxan treatment increased the blood glucose level in treated rabbits compared to the control rabbits.

\subsubsection{Alloxan induced diabetics and comparison with bitter melon fruit}

Blood glucose level of different groups of rabbits are presented in Table 1.The study was revealed that glucose level was the lowest in group $\mathrm{C}$, which was treated with bitter melon compare to the B group. The effect of fruit suspension at a dose of $250 \mathrm{gm} / \mathrm{kg}$ body weight in lowering blood sugar level showed statistically significant Comparison with $\mathrm{B}$ group. We have evaluated the suspension of the unripe fruit of the Momordicacharantia (Bitter melon) was assessed for its antidiabetic activity in Alloxan induced diabetic rabbits. The blood sugar levels were highly decreased with a treatment of high dose of extract. The blood sugar levels are almost comes to the Normal levels. The present results are agreed with other results. Sarkar et al., 1996; Miura et al., 2001; Leatherdale et al., 1981 and Akhar et al., 1981; suggested that results of this study show that oral administration of an extract of Momordicacharantia fruit at an appropriate dosage may be good alternative antidiabetic agent in Alloxan induced diabetics.

\subsubsection{Alloxan induced diabetics and comparison with garlic}

Blood glucose level of different groups of rabbits are presented in Table 1.The study was revealed that glucose level was the low in group $\mathrm{D}$, which was treated with garlic compare to the $\mathrm{B}$ group. The effect of seed 
suspension at a dose of $750 \mathrm{mg} / \mathrm{kg}$ body weight in lowering blood sugar level showed statistically significant Comparison with B group. We have evaluated the use of garlic was assessed for its antidiabetic activity in Alloxan induced diabetic rabbits. The blood sugar levels were highly decreased with a treatment of high dose of extract. The blood sugar levels are almost comes to the Normal levels. The present results are agreed with other results. (Sharma et al., 1977; Sheela and Augusti, 1992; Jain et al., 1973); the results of this study indicate that a dose of $750 \mathrm{mg} / \mathrm{kg}$ body weight of Allium Sativum might be a beneficial oral hypoglycemic agents in Alloxan induced diabetes.

\subsubsection{Alloxan induced diabetics and comparison between different groups of rabbits}

The fall in the blood sugar was compared among the groups of animals.

The study was reveled that blood glucose level was the lowest in group E compare to the $\mathrm{C}$ and $\mathrm{D}$ group, which was treated with bitter melon fruit and garlic extract. The effect of this combined treatment significantly $(\mathrm{p} \leq .0 .05)$ affects the blood glucose level.

Table 1. Effects of bitter melon fruit and garlic and combined treatment on blood glucose $(\mathrm{m} \mathrm{mol} / \mathrm{L}$, mean $\pm S E)$ concentration in Alloxan induced diabetic rabbits $(n=4)$.

\begin{tabular}{|c|c|c|c|c|}
\hline $\begin{array}{l}\text { Treatment } \\
\text { group }\end{array}$ & $\begin{array}{l}\text { Day 0 } \\
(\text { Mean } \pm \mathrm{SE})\end{array}$ & $\begin{array}{l}\text { Day } 7 \\
(\text { Mean } \pm \text { SE) }\end{array}$ & $\begin{array}{l}\text { Day } 14 \\
(\text { Mean } \pm \mathrm{SE})\end{array}$ & $\begin{array}{l}\text { Day } 21 \\
(\text { Mean } \pm \text { SE) }\end{array}$ \\
\hline A (Control) & $\begin{array}{ll}7.550 & \mathrm{~b} \pm .44064\end{array}$ & $7.725 \mathrm{~d} \pm .37053$ & $7.425 \mathrm{~d} \pm .24958$ & $7.875 \mathrm{~d} \pm .13150$ \\
\hline $\begin{array}{l}\text { B (Diabetic } \\
\text { control) }\end{array}$ & 28.33 a \pm .68845 & $27.00 \mathrm{a} \pm 1.15109$ & 23.48 a \pm .88729 & 19.02 a \pm .70401 \\
\hline $\begin{array}{l}\text { C (Alloxan } \\
\text { induction }+ \\
\text { Bitter melon) }\end{array}$ & 27.95 a \pm .72399 & 23.45 c \pm .75774 & 18.27 c \pm .71224 & $12.98 \mathrm{~b} \pm .45712$ \\
\hline $\begin{array}{l}\text { D (Alloxan } \\
\text { induction } \\
+ \text { Garlic) }\end{array}$ & 29.13 a \pm .63163 & $26.10 \mathrm{ab} \pm .75829$ & $21.27 \mathrm{~b} \pm .80971$ & $14.02 \mathrm{~b} \pm .46435$ \\
\hline $\begin{array}{l}\text { E (Alloxan } \\
\text { induction + } \\
{[\mathrm{K}+\mathrm{G}]} \\
\text { Combined) }\end{array}$ & 28.27 a \pm .82903 & $23.88 b c \pm .48541$ & $19.30 \mathrm{bc} \pm .80104$ & $11.25 \mathrm{c} \pm .33789$ \\
\hline
\end{tabular}

Values with the different superscripts in the same column are statistically significant $(\mathrm{P}<0.05)$. A, Control (without treatment); B, Alloxan induction (75mg); C, Bitter melon treatment (250gm); D, garlic treatment (750mg); E, combination of Bitter melon and garlic treatment.

\subsection{Body weight (gm)}

The percent increased in body weight gain in normal control rabbits (Group A, n=4) was $1133 \mathrm{gm}$. On the contrary, in diabetic control group (Group B, $\mathrm{n}=4$ ), the percentage of body weight loss was $1000 \mathrm{gm}$. The percent increased in body weight gain over 21 days in. Group $C(n=4)$, following oral administration of suspension of bitter melon@ $250 \mathrm{gm} / \mathrm{kg}$ was $1080 \mathrm{gm}$. In Group D ( $\mathrm{n}=4)$, following administration of garlic seeds @ $750 \mathrm{mg} / \mathrm{kg}$ for 21 days the percentage of body weight gain was $1085 \mathrm{gm}$. In Group E (n=4), following administration of bitter melon and garlic seeds @ previous doses for 21 days the percentage of body weight gain was $1168 \mathrm{gm}$ comparison with B group which is treated with Alloxan (Table 2). Here we see that the highest body weight gain is increase in garlic treatment group (D) than group A and B but little bit similar to the group C. The present results are agreed with other results. (Ugwuja E.I, Nwibo A.N, Ugwu N.C, and Aloke C; 2010); the results of this study indicate that a dose of $750 \mathrm{mg} / \mathrm{kg}$ body weight of Allium Sativum might be a beneficial for weight gainin Alloxan induced diabetes. 
Table 2. Effects of bitter melon fruit and garlic seed suspension and combined treatment on body weight $(\mathrm{gm})$ in Alloxan induced diabetic rabbits $(\mathrm{n}=4)$.

\begin{tabular}{llcccc}
\hline Treatment group & $\begin{array}{l}\text { Day 0 } \\
(\text { Mean } \pm \text { SE) }\end{array}$ & $\begin{array}{l}\text { Day 7 } \\
(\text { Mean } \pm \text { SE) }\end{array}$ & $\begin{array}{l}\text { Day 14 } \\
(\text { Mean } \pm \text { SE) }\end{array}$ & $\begin{array}{l}\text { Day 21 } \\
(\text { Mean } \pm \text { SE) }\end{array}$ \\
\hline A (Control) & $1056.0 \mathrm{a} \pm 21.34781$ & $1078.0 \mathrm{a} \pm 21.74665$ & $1083.0 \mathrm{ab} \pm 26.88711$ & $1133.0 \mathrm{a} \pm 20.56494$ \\
$\mathrm{~B}($ Diabetic control) & $1025.0 \mathrm{a} \pm 32.27486$ & $1020.0 \mathrm{a} \pm 31.09126$ & $1010.0 \mathrm{~b} \pm 29.72092$ & $1000.0 \mathrm{~b} \pm 32.40370$ \\
$\mathrm{C}($ Alloxan induction + & $1056.0 \mathrm{a} \pm 21.34781$ & $1048.0 \mathrm{a} \pm 20.56494$ & $1090.0 \mathrm{a} \pm 28.57738$ & $1080.0 \mathrm{a} \pm 20.81666$ \\
$\begin{array}{l}\text { Bitter melon) } \\
\text { D (Alloxan induction }+\end{array}$ & $1063.0 \mathrm{a} \pm 16.13743$ & $1062.0 \mathrm{a} \pm 14.93039$ & $1078.0 \mathrm{ab} \pm 18.87459$ & $1085.0 \mathrm{a} \pm 21.01587$ \\
$\begin{array}{l}\text { Garlic) } \\
\text { E (Alloxan induction }+\end{array}$ & $1075.0 \mathrm{a} \pm 14.43376$ & $1063 . \pm 10.30776$ & $1083.0 \mathrm{ab} \pm 11.08678$ & $1068.0 \mathrm{ab} \pm 13.14978$ \\
{$[\mathrm{~K}+\mathrm{G}]$ Combined) }
\end{tabular}

Values with the different superscripts in the same column are statistically significant $(\mathrm{P}<0.05)$. A, Control (without treatment); B, Alloxan induction $(75 \mathrm{mg})$; C, Bitter melon treatment (150gm); D, Garlic treatment (250mg); E, combination of Bitter melon and Garlic treatment.

\section{3. \% PCV (Packed Cell Volume)}

The percentage of pack cell volumn of different treatment groups were shown in Table 3. The study was revealed that \% of PCV level was the highest in group E which was treated with both garlic and bitter melon compare to the A group. This treatment significantly $(\mathrm{p} \leq .0 .05)$ increase the pack cell volumnlevel in treated rabbits. The present results are agreed with other results of (Ochuko et al., 2013).

Table 3. \% PCV (Packed Cell Volume).

\begin{tabular}{|c|c|c|c|c|}
\hline Treatment group & $\begin{array}{l}\text { Day } 0 \\
(\text { Mean } \pm \text { SE) }\end{array}$ & $\begin{array}{l}\text { Day } 7 \\
(\text { Mean } \pm \text { SE) }\end{array}$ & $\begin{array}{l}\text { Day } 14 \\
(\text { Mean } \pm \text { SE) }\end{array}$ & $\begin{array}{l}\text { Day } 21 \\
(\text { Mean } \pm \text { SE) }\end{array}$ \\
\hline A (Control) & $40.47 \mathrm{ab} \pm 0.779$ & $40.08 \mathrm{ab} \pm 0.368$ & $40.70 \mathrm{a} \pm 0.393$ & 41.25 bc \pm 0.379 \\
\hline B (Diabetic control) & $38.97 \mathrm{ab} \pm 1.057$ & $37.83 c \pm 0.829$ & $37.00 \mathrm{a} \pm 0.778$ & $35.82 \mathrm{~d} \pm 0.475$ \\
\hline $\begin{array}{l}\text { C (Alloxan induction } \\
+ \text { Bitter melon) }\end{array}$ & $38.17 \quad b \pm 0.818$ & 38.75 bc \pm 0.517 & $40.33 \mathrm{a} \pm 0.600$ & 40.72 c \pm 0.549 \\
\hline $\begin{array}{l}\text { D (Alloxan induction } \\
\text { + Garlic) }\end{array}$ & $40.28 \mathrm{ab} \pm 0.437$ & $40.42 \mathrm{ab} \pm 0.301$ & $41.03 \mathrm{a} \pm 0.428$ & $42.17 \mathrm{ab} \pm 0.256$ \\
\hline $\begin{array}{l}\text { E (Alloxan induction } \\
+[\mathbf{K}+\mathbf{G}] \text { Combined) }\end{array}$ & $41.33 \mathrm{a} \pm 0.60191$ & $41.70 \mathrm{a} \pm 0.535$ & $42.20 \mathrm{a} \pm 0.533$ & $42.95 \mathrm{a} \pm 0.554$ \\
\hline
\end{tabular}

\subsection{Hb (Hemoglobin) gm/dl}

The Hb (Hemoglobin) gm/dl concentration of different treatment groups were shown in Table 4. The study was revealed that the $\mathrm{Hb}$ (Hemoglobin) $\mathrm{gm} / \mathrm{dl}$ concentration was the highest in group $\mathrm{E}$ which was treated with both garlic and bitter melon compare to the A group. This treatment significantly $(\mathrm{p} \leq .0 .05)$ increase the $\mathrm{Hb}$ (Hemoglobin) $\mathrm{gm} / \mathrm{dl}$ concentration in treated rabbits. The present results are agreed with other results of (Alamgeer et al., 2012).

Table 4. Hb (Hemoglobin) gm/dl.

\begin{tabular}{lllll}
\hline Treatment group & $\begin{array}{l}\text { Day 0 } \\
\text { Mean } \pm \text { SE) }\end{array}$ & $\begin{array}{l}\text { Day 7 } \\
(\text { Mean } \pm \text { SE) }\end{array}$ & $\begin{array}{l}\text { Day 14 } \\
\text { (Mean } \pm \text { SE) }\end{array}$ & $\begin{array}{l}\text { Day 21 } \\
(\text { Mean } \pm \text { SE) }\end{array}$ \\
\hline A (Control) & $11.93 \mathrm{a} \pm 0.523$ & $12.10 \mathrm{a} \pm 0.609$ & $12.43 \mathrm{a} \pm 0.554$ & $12.60 \mathrm{a} \pm 0.636$ \\
$\mathrm{~B}$ (Diabetic control) & $12.15 \mathrm{a} \pm 0.569$ & $12.10 \mathrm{a} \pm 0.430$ & $11.82 \mathrm{a} \pm 0.480$ & $11.90 \mathrm{a} \pm 0.341$ \\
$\begin{array}{l}\text { (Alloxan induction + Bitter } \\
\text { melon) }\end{array}$ & $12.20 \mathrm{a} \pm 0.628$ & $12.07 \mathrm{a} \pm 0.652$ & $12.55 \mathrm{a} \pm 0.684$ & $12.43 \mathrm{a} \pm 0.618$ \\
$\begin{array}{l}\mathrm{D} \quad \text { (Alloxan induction } \\
\text { Garlic) }\end{array}$ & $+12.52 \mathrm{a} \pm 0.356$ & $12.52 \mathrm{a} \pm 0.352$ & $12.48 \mathrm{a} \pm 0.390$ & $12.57 \mathrm{a} \pm 0.370$ \\
$\begin{array}{l}\mathrm{E} \quad \text { (Alloxan induction } \\
{[\mathrm{K}+\mathrm{G}] \text { Combined) }}\end{array}$ & $+12.65 \mathrm{a} \pm 0.330$ & $12.57 \mathrm{a} \pm 0.368$ & $12.60 \mathrm{a} \pm 0.387$ & $12.82 \mathrm{a} \pm 0.295$ \\
\hline
\end{tabular}


3.5. ESR (Erythrocyte Sedimentation Rate) $\mathrm{mm} / \mathrm{h}$

The (Erythrocyte Sedimentation Rate) $\mathrm{mm} / \mathrm{h}$ of different treatment groups were shown in Table 5. The study was revealed that ESR was highest in group B treated with Alloxan and lowest in group E.

Table 5. ESR (Erythrocyte Sedimentation Rate) $\mathrm{mm} / \mathrm{h}$.

\begin{tabular}{llllll}
\hline Treatment group & $\begin{array}{l}\text { Day 0 } \\
(\text { Mean } \pm \text { SE) }\end{array}$ & $\begin{array}{l}\text { Day 7 } \\
(\text { Mean } \pm \text { SE) }\end{array}$ & $\begin{array}{l}\text { Day 14 } \\
(\text { Mean } \pm \text { SE) }\end{array}$ & $\begin{array}{l}\text { Day 21 } \\
(\text { Mean } \pm \text { SE) }\end{array}$ \\
\hline A (Control) & $1.875 \mathrm{ab} \pm 0.268$ & $1.700 \mathrm{~b} \pm 0.216$ & $1.900 \mathrm{~b} \pm 0.227$ & $1.950 \mathrm{bc} \pm 0.225$ \\
B (Diabetic control) & $1.850 \mathrm{~b} \pm 0.064$ & $2.200 \mathrm{ab} \pm 0.108$ & $2.750 \mathrm{a} \pm 0.165$ & $3.525 \mathrm{a} \pm 0.103$ \\
C (Alloxan induction & $2.550 \mathrm{a} \pm 0.322$ & $2.300 \mathrm{a} \pm 0.187$ & $2.075 \mathrm{~b} \pm 0.085$ & $2.150 \mathrm{~b} \pm 0.086$ \\
+ + Bitter melon) & & & & & \\
$\begin{array}{l}\text { D (Alloxan induction } \\
\text { + Garlic) }\end{array}$ & $2.150 \mathrm{ab} \pm 0.119$ & $2.000 \mathrm{ab} \pm 0.040$ & $1.775 \mathrm{~b} \pm 0.062$ & 1.675 & $\mathrm{~cd} \pm 0.062$ \\
$\begin{array}{l}\text { E (Alloxan induction } \\
+ \text { [K+G] Combined) }\end{array}$ & $2.350 \mathrm{ab} \pm 0.155$ & $2.175 \mathrm{ab} \pm 0.165$ & $1.825 \mathrm{~b} \pm 0.110$ & 1.525 & $\mathrm{~d} \pm 0.110$ \\
\hline
\end{tabular}

\section{Conclusions}

This experiment supports the traditional usage of the herbal preparation by Ayurvedic physicians for the control of diabetes. Momordicacharantiahas the potentiality to be used as an adjuvant in the treatment of Diabetes but which requires further study. Also Allium Sativum may be the beneficial for oral hypoglycemic agents in diabetic patients. Moreover combination of Momordicacharantia and Allium Sativum will be used for the treatment of diabetic patients without any health hazzards. However, due to some short comings only one trial is performed in short term basis and modern equipments are also not available. Before field application as the hypoglycemic agents in case of diabetic patients further trial on a large scale basis is needed and also to make the findings more accurate and effective further study is essential to see any adverse effect in relation to histopathology before making a definite conclusion.

\section{Acknowledgments}

This work was supported by the department of Physiology \& Pharmacology, Hajee Mohammad Danesh Science \& Technology University, Dinajpur, Bangladesh.

\section{Conflict of interest}

None to declare.

\section{References}

Ahmed, EA deghate, AK Sharma, DJ Pallot and J Singh, 1998. Effects of Momordicacharantia fruit juice on islet morphology in the pancreas of the streptozotocin-diabetic rat. Diabetes Res. Clin. Pract., 40: 145-151.

Akhar MS, MA Athar and M Yaqub, 1981. Effect of Momordicacharantia on blood glucose level ofnormal and alloxan-diabetic rabbits. Planta Medica, 42: 205-212.

Alamgeer, Muhammad Naveed Mushtaq, Sajid Bashir, Muhammad Rashid, Muhammad Nasir Hayat Malik, Shazia Akram Ghumman, Hafiz Muhammad Irfan, Muhammad Akram, Abdul Qayyum Khan and HaroonUr-Rashid, 2012. Hypoglycemic and hematological effects of aqueous extract of Thymus serpyllumLinn. inalloxan-induced diabetic rabbits. African Journal of Pharmacy and Pharmacology, 6: 2845-2850.

Bailey CJ and C Day, 1989. Traditional plants medicines as treatments for diabetes. Diabetes Care, 12:552- 556.

Bonar JR, 1980. Diabetes. 2nd ed. Medical Examination Publishing Company Inc., pp. 25-27.

Chen Q, LLY Chan and ETS Li, 2003. Bitter melon (Momordica charantia) reduces adiposity, lowers serum insulin and normalizes glucose tolerance in rats fed a high fat diet. J. Nutr., 133: 1088-1093.

Gordsky GM, 1982. Diabetes.31: 45-53.

Mader HF, 1990. Treatment of hyperlipidaemia with garlic-powder tablets: Evidence from the German Association of General Practitioners' multicentric placebo-controlled double-blind study. Arzneimittelforschung., 40:1111-6.

Durak I, HS Oztürk, E Olcay and C Güven, 2002. Effects of garlic extract supplementation on blood lipid and antioxidant parameters and atherosclerotic plaque formation process in cholesterol-fed rabbits. J. Herb Pharmacother., 2: 19-32.

Durak I, M Kavutcu and B Aytaç, 2004. Effects of garlic extract consumption on blood lipid and oxidant/antioxidant parameters in humans with high blood cholesterol. J. Nutr. Biochem.,15: 373-7. 
Kojuri J, AR Vosoughi and M Akrami, 2007. Effects of anethum graveolens and garlic on lipid profile in hyperlipidemic patients. Lipids Health Dis., 6:5

Jain R, C Vyas and O Mahatma, 1973. Letter: Hypoglycemic action of onion and garlic. Lancet, 2:1491.

Kumar R, S Balaji, TS Uma and PK Sehgal, 2009. Fruit extracts of Momordicacharantiapotentiate glucose uptake and up-regulate Glut-4, PPAR $\gamma$ and PI3K. J. Ethnopharmacol., 126: 533-537.

Leatherdale BA, RK Panesar, G Singh, TW Atkins, CJ Bailey and AHC Bignell, 1981. Improvement in glucose tolerance due to Momordicacharantia (karela). Br. Med. J. (Clin Res Ed)., 282:1823-1824.

Lenzen S, 2008. The mechanisms of alloxanandstreptozotocin-induced diabetes. Diabetologia., 51: 216-226.

Merck Index, 1976. 9th ed. Merck \& Company, Inc. Rahway NJ, USA, p.274.

Miura T, C Itoh, N Iwamoto, M Kato , M Kawai, SR Park and I Suzuki, 2001. Hypoglycemic activity of the fruit of the Momordicacharantia in type 2 diabetic mice. J. Nutr. Sci. Vitaminol. (Tokyo), 47:340-344.

Murray MT and JE Pizzorno, 1999. Allium sativum (garlic). In: Textbook of natural medicine. $2^{\text {nd }}$ Edition. (eds. J.E. Pizzorno Jr. and M.T. Murray), Edinburgh: Churchill Livingstone. 571-577.

Nerurkar PV, YK Lee, M Motosue, K Adeli and VR Nerurkar, 2008. Momordica charantia (bitter melon) reduces plasma apolipoprotein B-100 and increases hepatic insulin receptor substrate and phosphoinositide-3 kinase interactions. Br. J. Nutr., 100:751-759.

Ochuko L, AT Erukainure Osaretin, O Ebuehi, Folasade, Adeboyejo, Muhammad Aliyu, 2013. Hematological and biochemical changes in diabetic rats fed with fiber-enriched cake. Journal of Acute Medicine, 3:39-44.

Ojo RJ, AE Memudu, CO Akintayo and IS Akpan, 2012. Effects of pre-induction administration of Allium sativum on some biochemical parameters in alloxan induced diabetic rats. Research Journal of Applied Sciences, Engineering and Technology, 4: 5129-5135.

Sarkar S, M Pranava and R Marita, 1996. Demonstration of the hypoglycemic action of Momordicacharantia in a validated animal model of diabetes. Pharmacol Res., 33:1-4.

Sharma K, R Gupta, S Gupta and K Samuel, 1977. Antihyperglycemic effect of onion: effect on fasting blood sugar and induced hyperglycemia in man. Indian J. Med. Res., 5: 422-429.

Sheela C, and K Augusti, 1992. Antidiabetic effects of S-allyl cysteine sulphoxide isolated from garlic Allium sativum Linn. Indian J. Exp. Biol., 30:523-526.

Sridhar M, Vinayagamoorthi, V Arul Suyambunathan, Z Bobby and N Selvaraj, 2008. Bitter gourd (Momordica charantia) improves insulin sensitivity by increasing skeletal muscle insulin-stimulated IRS-1 tyrosine phosphorylation in high-fat-fed rats. Br. J. Nutr., 99: 806-812.

Tasaka Y, Y Inoue, H Matsumoto and Y Hirata, 1988. Changes in plasma glucagon, pancreatic polypeptide and insulin during development of alloxan diabetes mellitus in dog. Endocrinol., 35:399-404.

Wadkar KA, CS Magdum, SS Patil and NS Naikwade, 2008. Antidiabetic potential and Indian medicinal plants. Journal of Herbal Medicine and Toxicology, 2: 45-50.

West E, OR Simon and EY Morrison, 1996. Streptozotocin alters pancreatic beta-cell responsiveness to glucose within six hours of injection into rats. West Indian Med J., 45:60-62. 